ERRATUM

Aytekin Guven • Fatma Inanc • Metin Kilinc

Hasan Ekerbicer

\title{
Plasma homocysteine and lipoprotein (a) levels in Turkish patients with metabolic syndrome
}

\section{Heart Vessels (2005) 20:290-295}

The article cited above should have appeared as a Clinical investigation in Original articles, not as a Case report.

\footnotetext{
A. Guven $(\square)$

Department of Cardiology, School of Medicine, Kahramanmaras

Sutcu Imam University, Kahramanmaras, Turkey

F. Inanc $\cdot$ M. Kilinc

Department of Biochemistry, School of Medicine, Kahramanmaras

Sutcu Imam University, Kahramanmaras, Turkey

H. Ekerbicer

Department of Public Health, School of Medicine, Kahramanmaras

Sutcu Imam University, Kahramanmaras, Turkey
} 